\title{
"FISCELLAS IUNCO TEXENS" \\ SOME CLASSICAL ALLUSIONS IN JEROME'S VITA HILARIONIS, CH. $5^{1}$
}

\begin{abstract}
Summary: The study focuses on a hidden classical allusion that has remained undetected in the biography of St. Hilarion. The young monk, tempted by carnal desire, tries to escape sin by fasting, praying and basket-weaving. Describing this last method, Jerome refers not only to the well-know monastic activity and the sentence of St. Paul - qui non operatur non manducet - but depicts basket-work as a remedy for love, an allusion to the erotic context of Virgil's Third Eclogue.
\end{abstract}

Key words: classical allusion, biography, St. Hilarion, Jerome, St. Paul, qui non operatur non manducet, Aegyptian monasticism, Virgil, Third Eclogue.

Writing about Saint Jerome's relationship to the classical authors, the first thought coming to mind might be the famous sentences in Letter 22: Quid facit cum psalterio Horatius? cum evangeliis Maro? Cum apostolo Cicero? ${ }^{2}$ The indignant words written in 384, after his dream on Holy Saturday, show us one side of Jerome's double-edged attitude towards classical literature. As a Christian he felt himself obliged to condemn pagan authors. On the other hand, it is a well-known fact that he never ceased reading and admiring the works he condemned. The aim of the present study is to illustrate his lifelong endeavour to reach an equilibrium between ascetism and culture in case of his Vita Hilarionis.

The pseudo-biography written in 391 in Betlehem belongs to his second creative period. In terms of his relation to the classics this period can be characterized by the preface of his commentar on the Epistle to the Galateans:

Nobis propositum est incircumcisos homines non introducere in templum Dei, et ut simpliciter fatear, multi iam anni sunt quod haec legere desivimus. Quindecim anni sunt, ex quo in manus meas numquam Tullius, numquam Maro, numquam gentilium litterarum quidlibet auctor ascendit. $^{3}$

\footnotetext{
${ }^{1}$ This work was supported by the Hungarian National Research Fund (OTKA F 023066).

2 Ep. 22, 29.

${ }^{3}$ In Galatas 2-3.
} 
It is widely known that this claim is not true, as shown also by the Vita Hilarionis. This biography, composed after the Vita Pauli and Vita Malchi, is the ripest and most advanced product of a literary experiment. At the heart of his endeavour is the attempt to mix pagan forms with ascetic thoughts, and thus to integrate the classical heritage into the new Christian world. It is well known, that the three Vitas borrow the structures and tools of classical genres (especially those of the novel) for hagiography and thus display significant differences from the first Christian biography written by Athanasios.

The Greek father composed his Vita Antonii in order to provide an example for his monk-readers and to help them in their way toward moral perfection, whereas Jerome's biographies do not contain paraineses on theological or ascetical topics. On the contrary, his works are rich in amusing details, adventures and allusions to classical texts. Jerome's attempt at creating a new literary form did not meet with full success either among his contemporary readers or among more modern ones. For example M. Fuhrmann ${ }^{4}$ speaks of a type of degradation (Herunterkommen) in Jerome's works in comparison with the Vita Antonii. The Greek father's opus dealing with theological problems and adressed to a monastic audience tries to answer philosophical questions concerning the relationship to God and the mission of Christians in the world. That is why his work can be called the mediator of a certain interpretation of the world, Weltdeutung. As far as Jerome is concerned, his works are full of miracles and wondrous turns, they are composed in a colourful style, they want to impress the imagination of his readers and create a world of fantasy - in other words, a Weltsurrogat instead of a Weltdeutung. ${ }^{5}$

Chapter 5 of the Vita Hilarionis offers a very similar picture to the famous description in Letter 22, which represents the mental crisis of Jerome before his Holy Saturday dream. The young Hilarion - as well as the young Jerome - is tempted by the world, by carnal desires:

Titillabat itaque sensus eius, et pubescenti corpori solita voluptatum incendia suggerebat. Cogebatur tirunculus Christi cogitare, quod nesciebat, et eius rei animo pompam volvere, cuius experimenta non noverat. Iratus itaque sibi, et pectus pugnis verberans (quasi cogitationes caede manus posset excludere): Ego, inquit, aselle, faciam, ut non calcitres: nec te hordeo alam, sed paleis. Fame te conficiam et siti: gravi onerabo pondere; per aestus indagabo et frigora, ut cibum potius quam lasciviam cogites. Herbarum ergo succo et paucis caricis post triduum vel quatriduum deficientem animam sustentabat, orans frequenter et psallens, et rastro humum fodiens, ut jejuniorum laborem operis duplicaret. Simulque fiscellas junco texens aemulabatur Aegyptiorum monachorum dis-

${ }^{4}$ FuHRmanN, M.: Die Mönchgeschichte des Hieronymus. Formexperimente in erzählender Literatur. Christianisme et formes littéraires de l'antiquité tardive en Occident. Entretiens Hardt XXIII, 1977, 41-101.

${ }^{5}$ FUHRMANN, op. cit. (note 4), 87. 
ciplinam, et Apostoli sententiam, dicentis: qui autem non operatur, non manducet, ${ }^{6}$ sic attenuatus, et in tantum exeso corpore, ut ossibus vix haeret. $^{7}$

The situation is a common one in hagiography: the monk (or the hermit) is tempted by demonical forces and tries to escape them using the methods of fasting, praying and working. Unlike other sources, this text - narrating the first temptation of Hilarion - concentrates on one type of temptation, the lure of love. There is no word about other sorts of sin, such as pride, disobedience, greed nor - as in Jerome's case - is there mention of classical literature. Its tendency to focus on bodily sin might throw a new light on his methods of escape, that is fasting and working, and may suggest a classical origin.

As far as fasting is concerned, the young Hilarion, turning to his own body, calls it a donkey ${ }^{8}$ and threats the recalcitrant animal: he will no longer be fed with barley, but will have to make do with hay. There is no need for a lengthy argument: as numerous texts testify, the male donkey in pagan literature, as a constant member of Dionysos' escort, symbolizes lechery and sexual desire. ${ }^{9}$ In fact, this is not the only case of Jerome using this symbolic animal for representing bodily sin: in $\mathrm{Ch} .8$ we hear about the Devil, who springs on the monk's back as a rider or agitator, mocking and instigating him. ${ }^{10}$ There is another passage in Jerome's epistology as well, where the author uses the motif of a donkey linked to fasting and carnal pleasures, in this case writing about how to educate a Christian girl. ${ }^{11}$ (Speaking about the donkey on which Jesus Christ rode into Jerusalem on Palm Sunday, Jerome uses the female form of this noun. ${ }^{12}$ )

Returning to fasting, it is an old Aristotelian idea that the temperature of the body can be reduced by moderate eating and avoiding certain kinds of food, and that in this way one can get rid of carnal desires as well. Jerome knew this theory well, and in fact, from a direct source. (This is surprising because Jerome did not read

${ }^{6}$ Cf. 2 Thess. 3, 10.

${ }^{7}$ Vita Hilarionis (hereafter $\mathrm{VH}$ ) Ch. 5.

${ }^{8}$ For the formal and contextual relationship of the VH and Apuleius' novel, as well as the erotic charges raised against the two authors and Jerome's letter to Asella (one of the nobildonnas associated with him at Rome), cp. WeInGarten, S.: Jerome and the Golden Ass. Studia Patristica 33, 1997, $382-389$.

${ }^{9}$ Cf. RACh VI, 1966, 565-595, s.v. Esel (by I. OPELT)

${ }^{10}$ VH. c. 6: Oravit semel fixo in terram capite, et ut natura fert hominum, abducta ab oratione mens nescioquid aliud cogitabat: insiliit dorso eius agitator et latere calcibus, cervicem flagello verberans, Eia, inquit, cur dormitas? Cachinnansque desuper, si defecisset, an hordeum vellet accipere, sciscitabatur. (Although the word asinus does not occur in these sentences, the unnamed animal might well be a donkey because of the mention of barley (hordeum): barley is a food for donkeys, while the fodder of horses is oat, ef. Athenaeus, Deipn. 10,456 f.)

${ }^{11}$ Ep. 107, 10: Displicent mihi in teneris vel aetatibus longa et immoderata ieiunia, quibus iunguntur ebdomades et oleum in cibo ac poma vitantur. Experimento didici asellum in via, cum lassus fuerit, diverticula quaerere.

${ }^{12}$ Ep. 22, 24: Mittit discipulos, ut in pullo asinae curis te saecularibus solvant. - Ep. 22, 41 : Tunc vere super asinam Dominus ascendet et caelestem Hienusalem ingredietur. 
most Greek authors he refers to in the original, and he usually only knows their names. ${ }^{13}$ ) Still, in Letter 54 Jerome mentions Galen as his source on this topic:

Aiunt medici et qui de humanorum corporum scripsere naturis praeci-

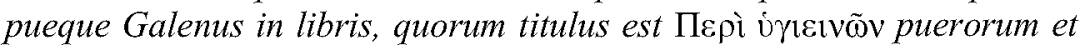
iuvenum ac perfectae aetatis virorum mulierumque corpora insito calore fervere et noxius esse his aetatibus cibos, qui calorem augeant, sanitatique conducere frigida quaeque in esu et potu sumere, sicut e contrario senibus, qui pituita laborarent et frigore, calidos cibos et vetera vina prodesse ... Et, ut quod sentio loquar, nihil sic inflammat corpora et titillat $^{14}$ membra genitalia nisi indigestus cibus ructusque convulsus. ${ }^{15}$

In sum, almost all of Jerome's works which are adressed to young Christians, either religious or lay, seem to contain advice about fasting as a means of escaping the lure of love.

As a result of his fasting, Hilarion was reduced to almost skin and bone. The expression vix ossibus haeret needs special attention, being the only quotation in Chapter 5 that can be identified at once: the phrase comes from Vergil's Third Eclogue (vv. 102-103).

The most important modern discussion of Jerome's technique of quotation is H. Hagendahl's book. ${ }^{16}$ The author tried not only to add new items to the earlier lists of quotations, but also to create a typology, dividing the citations into two groups. The first one is made up of 'hidden' quotations that are part of a sentence and can be detected only by their metrical form, like our vix ossibus haeret. The recognition of this type can be difficult for modern readers because "some of these phrases may well be unconscious echoes, for like every educated man of the later Empire, Jerome's mind was saturated with Vergil." ${ }^{17}$ The group of 'open' quotations are made up of citations where Jerome explicitly names his classical sources, identifying them or referring to them using an epithet. ${ }^{18}$ According to A. Cameron five items of hidden quotations can be identified in the Vita Hilarionis. ${ }^{19}$

Returning to fasting and the phrase vix ossibus haeret, this formula appears to have been Jerome's favourite because he uses it several times in his Letters: twice in

\footnotetext{
${ }^{13}$ COURCELle, P.: Les lettres grecques en Occident. Paris 1948, esp. 49-78 and 111-115.

${ }^{14}$ The word titillat seems to be Jerome's term for the awakening of bodily desire, ef. Ep. 52, 3. adulescentia multa corporis bella sustineat et inter incentiva vitiorum et carnis titillationes quasi ignis in lignis viridioribus suffocetur et suum non possit explicare fulgorem, and Ep. 128, 2: carnis illecebra et dulcis titillatio corporis.

${ }^{15}$ Ep. 54, 9-10.

${ }^{16}$ HAGENDAHL, H.: Latin Fathers and the Classics. Goeteborg 1958, esp. 301-305.

${ }^{17}$ CAMERON, A.: Echoes of Vergil in St. Jerome's Life of St. Hilarion. CPh 63, 1968, 55-56.

${ }^{18} \mathrm{Cp}$. VH Ch. 1: Scripturus vitam beati Hilarionis habitatorem eius invoco Spiritum Sanctum, ut qui illi virtutes largitus est, mihi ad narrandas eas sermonem tribuat, ut facta dictis exaequentur. Eorum enim, qui fecere virtus (ut ait Crispus) tanta habetur, quantum eam verbis potuere extollere praeclara ingenia. (Cf. Sall. Cat. 8, 4; 3, 2.)

${ }^{19}$ CAmeron, op. cit. (note 17): VH Ch. 1; Cic. Arch. 10, 24 and HA Vit. Probi 1; Ch. 6; Georg. 2, 470; Ch. 13, Aen. 6, 476 and 12, 72; Ch. 30, Aen. 1, 149; Ch. 38, Aen. 5, 611 .
} 
Letter 22, about the experiences of his own temptation and remorse in the desert, ${ }^{20}$ and once in Letter 117, referring to a character of Greek mythology (probably Echo) who wasted away because of unhappy love. ${ }^{21}$ Although the same formula describing a fasting monk can be found in other ascetic works as well, ${ }^{22}$ there can be no doubt ${ }^{23}$ that Jerome's source in this case is Vergil, and, indirectly, the Fourth Idyll of Theocritus. ${ }^{24}$ Although the context of the classical versions referring to animals instead of man differs from Jerome's text, there is something common in his words and the bucolic authors, namely the motif of desire. In Theocritus' poem the cows are longing for their master who is away. Vergil slightly changes the context and intentionally alludes to the desire of love: Idem amor exitium est pecori pecorisque magistro. As far as Theocritus is concerned, there is no evidence that Jerome had read his works. Similarly to Greek prose authors, Jerome knows only the names of Greek poetry. ${ }^{25}$ That is why we should regard Vergil - and the erotic background of his poem as Jerome's only source.

In my opinion the quotation vix ossibus haeret can be regarded as more than a hidden quotation, whose only aim was to enrich the style. The sentence might also recall the situation in which it was uttered, and thus give some sense of correspondence between the poem and the biography. Fortunately there is evidence that Jerome was reading the Vergil's Bucolics at the time when he was writing his Hilarion. In his Apology, Rufin, his one-time friend accuses Jerome of reading and teaching secular literature in his monastic school at Betlehem, and among other pagan authors he also mentions Vergil. ${ }^{26}$ On the other hand, it is Jerome himself who complains about his fellow clerics reading secular poems (in this case showing up his rigorous attitude). ${ }^{27}$

${ }^{20}$ Ep. 22, 7: Cotidie lacrimae, cotidie gemitus, et si quando repugnantem somnus imminens oppresisset, nuda humo vix ossa haerentia collidebam; Ep. 22, 30: Dum ita me antiquus serpens illuderet, in media ferme quadragesima medullis infusa febris corpus invasit exhaustum et sine ulla requie - quod dictu quoque incredibile sit - sic infelicia membra depasta est, ut ossibus vix haerem. Jerome does not use the phrase mechanically, e. g. Ep. 22, 17: Oblitus sum manducare panem meum; a voce gemitus mei adhaesit os meum carni meae.

${ }^{21}$ Ep. 117, 7: Legimus in scholis pueri et spirantia in plateis aera conspeximus aliquem ossibus vix haerentem inlicitis arsisse amoribus et ante vita caruisse, quam peste.

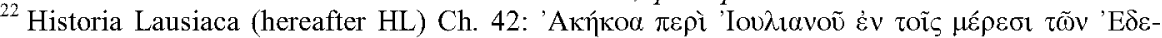

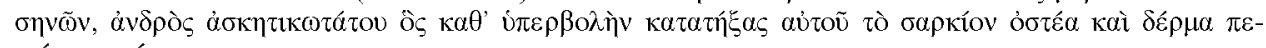

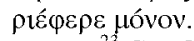
$66-70$.

${ }^{23} \mathrm{Cp}$. GODEL, R.: Réminiscences de poètes profanes dans les lettres de St. Jerome. MH 21, 1964,

${ }^{24}$ Ecl. 3, 100-104: Heu, heu! quam pingui macer est mihi taurus in ervo! / Idem amor exitium est pecori pecorisque magistro. / Hi certe - neque amor causa est-vix ossibus haerent / nescio quis teneros oculus mihi fascinat agnos.

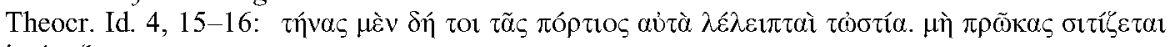

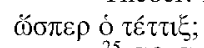

${ }^{25} \mathrm{Cf}$. COURCELLE, op. cit. (note 13), 49-52.

${ }^{26}$ Apol. in Hier. 2, 8: ... in monasterio positus in Betlehem ante non multo adhuc tempore, partes grammaticas exsecutus sit et Maronem suum comicosque ac Lyricos et historicos auctores traditis sibi ad discendum Dei timorem puerulis exponebat.

${ }^{27}$ Ep. 21, 13: Daemonum cibus est carmina poetarum, saecularis sapientia, rhetorica pompa verborum... At nunc etiam sacerdotes dei omissis evangelis et prophetis videmus comoedias legere, 
The fact that the formula vix ossibus haeret can be regarded as an allusive pattern to one bucolic poem might shed new light on the topic of working as well. At first sight manual work might seem a typical way of escaping from temptation and the type of work, weaving baskets is common as well. Although the historical authenticity of the Vita Hilarionis is a hotly debated question, ${ }^{28}$ both ancient sources and modern historians dealing with ascetic life in Late Antiquity speak about basketwork as a characteristic monastic activity. This type of work is especially common in Egypt, where the monk, living in the desert, is forced by the climatic and geographical conditions to remain in the same place. His cell is the scene for his praying, fasting and working which usually means basketwork and rope-making. (In Syria, on the other hand, the conditions of life were not so hard as in Egypt, where survival is in itself a difficult task. The Syrian monk was not restricted to his cell, he could walk to the city and take part in social life. That is why Syrian monasticism developed other form of asceticism: wearing chains, standing on the top of pillars for a life, and other extreme forms of self-torment in order to achieve a bodyless state, to live a vita angelica on earth. ${ }^{29}$ ) Hilarion, weaving baskets in his cell, represents the Egyptian way of monastic life.

Work is an important part of ascetic life. Monks do weaving for different purposes: they make baskets (or ropes for animals ${ }^{30}$ ) in order to sell them and this way acquire food, ${ }^{31}$ they give the money earned with basketwork to the poor, or, like the greedy monk in Jerome's Letter 22, keep it for themselves. ${ }^{32}$ Sometimes the basket is a gift to their brothers visiting them, as described in the Vita Antonii, ${ }^{33}$ or given as inheritance to their spiritual children. ${ }^{34}$ By weaving they could provide themselves with tents or mats. ${ }^{35}$ In addition, in Greek sources, basketwork can be a special exercise in obedience ( $\tau \alpha \pi \varepsilon i ́ v \omega \sigma \iota)$ ): in a work ascribed to Athanasios we read about an abbot who sends his disciple to the market place in order to sell ten baskets but only one by one, in this way testing his compliance with orders. ${ }^{36}$ The most famous case is

amatoria bucolicorum versuum verba cantare, tenere Vergilium et id, quod in pueris necessitatis est, crimen in se facere voluntatis.

${ }^{28}$ For the shortcomings of Jerome's historical methods, cp. COLEIRO, E.: St. Jerome's Live of the Hermits. VigChr 11, 1957, 161-179. $80-101$.

${ }^{9}$ Cf. Brown, P.: The Rise and Function of the Holy Man in the Late Antiquity. JRS 61, 1971,

${ }^{30}$ Historia Monachorum. Edited by A.-J. FestugiÈRE. Bruxelles, 1961 (hereafter HM), 13, 44:

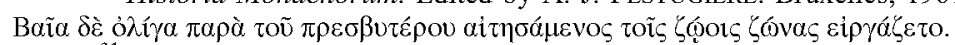

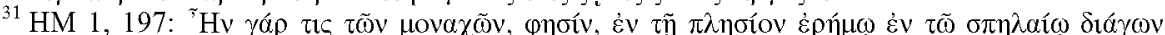

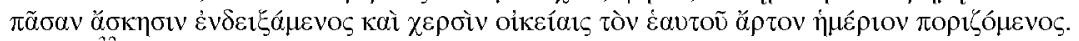

${ }^{32}$ Ep. 52, 3: labor manuum, unde praebantur elemosynae...; Ep. 22, 33: Quidem e fratribus parcior magis quam avarior ... centum solidos, quos lina texendo quaesierat, moriens dereliquit.

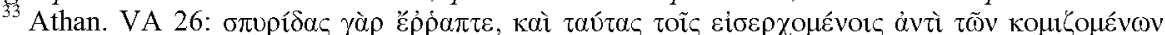

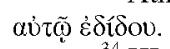

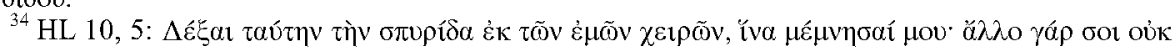

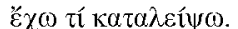

${ }^{35}$ VH 9: ... aestus et pluvias brevi tuguriunculo declinavit, quod junco et carice texuerat; VA

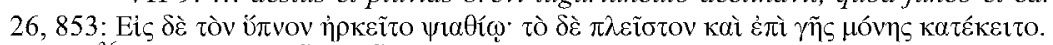

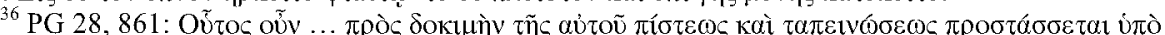

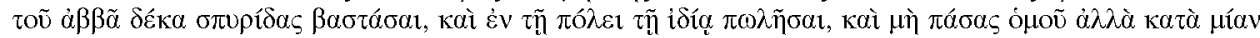

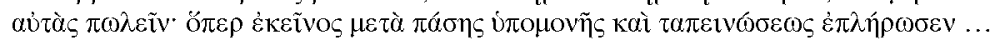


the story of Paulus Simplex's education who was ordered by his abbot, Antonius, to weave a basket ${ }^{37}$ then undo it, and weave it again and again. ${ }^{38}$

But working, of course, first of all is an important part of asceticism, the fulfilling of the apostolic command that we can read about in Vita Hilarionis as well: $\mathrm{O} \delta \grave{\varepsilon}$

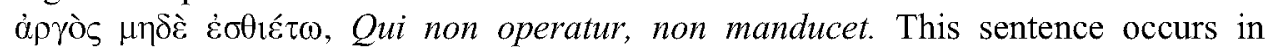

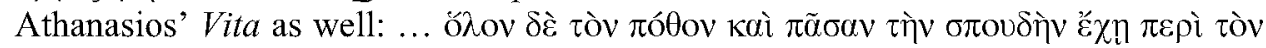

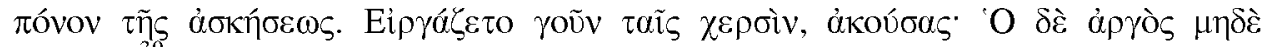
$\dot{\varepsilon} \sigma \theta t \varepsilon \dot{\varepsilon} \tau \omega^{39}$

Jerome often emphasizes the spiritual importance of work: praying and doing manual activity at the same time leave no room for thoughts to wander freely astray, and allow no possibility for the Devil's temptations. (In the Historia Lausiaca we can read about a monk whose perfection was so great that he was able to weave, talk to his brothers and heal an ill person at the same time. ${ }^{40}$ ) Handworking - as several Greek sources testify - is a way of reaching the salus animi. In connection with this topic, it would be interesting to examine more closely one passage of Letter 125, in which Jerome recalls the world of Vergil's Georgica in his exhortation to manual work and surveys a catalogue of occupations, among them basketwork. ${ }^{41}$ Similar lists can be found in the works of Greek ecclesiastic authors as well, for example in the works of Palladius ${ }^{42}$ and Theodoretus. ${ }^{43}$

At first sight, Jerome's account of working and especially basketwork appears identical to similar ideas in other Christian ascetic works, which represent basketwork as a fundamental supplementary activity to praying. Jerome's report about Hilarion's work, however, differs from them in its attitude. This can be illustrated by confronting it with a paralell passage of Vita Antonii, which will also serve as a spe-

${ }^{37}$ The first occurrence in Greek of the word ojupí $\zeta$ is in Herodotus $(5,27)$ referring to some fishing-tool. It can be found in Aristophanes ( $A c h .449$ and 469, Pax 1005) with the meaning of a basket used to carry fish, bread, and vegetables. $\Sigma \pi v \rho i ́ c$ occurs in the New Testament as well (Mt 15,27 and Mc 8,8 ) where it is used in the story of the miracle of bread and fish. Also, Saint Paul escapes from the Jews by being lowered from the top of the house into the street in a orupis (Act. Ap. 9, 25).

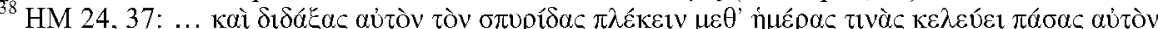

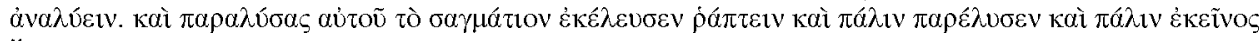
$\varepsilon \rho \rho \alpha \pi \tau \varepsilon v$.

${ }^{39}$ VA 26,844

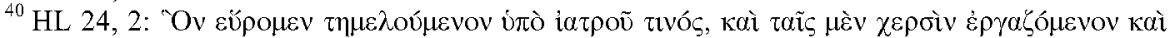

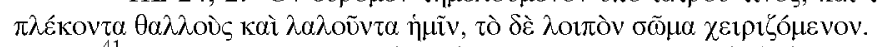

${ }^{41}$ Ep. 125, 11: Fac et aliquid operis, ut semper te diabolus inveniat occupatum... Vel fiscellam texe junco vel canistrum lentis plecte viminibus... Aegvptionum monasteria hanc morem tenent, ut nullum absque opere ac labore suscipiant, non tam propter victus necessaria quam propter animae salutem, ne vagetur perniciosis cogitationibus, et instar fornicantis Hierusalem omni transeunti divaricet pedes suos. Cp. ADKIN, N.: Vergil's Georgics and Jerome Epist. 125. 11, 3-4. WJb 22, 1998, 187-198.

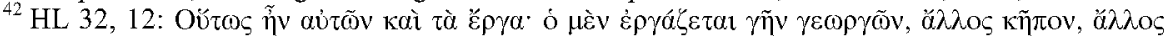

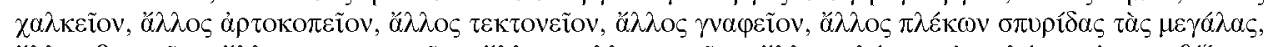

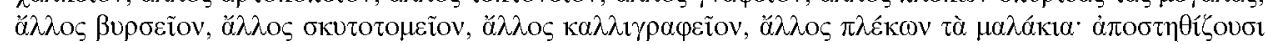

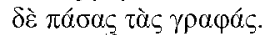

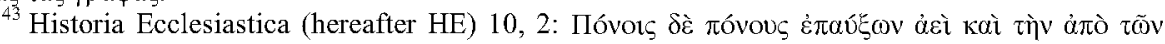

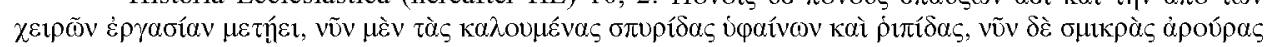

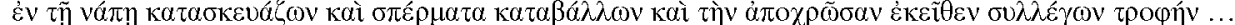

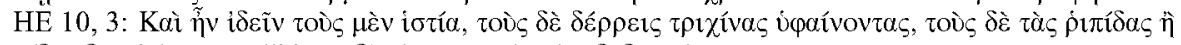

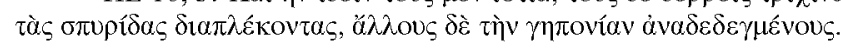


cific example of how the Vita Hilarionis intentionally emulates the work of Athanasius. $^{44}$

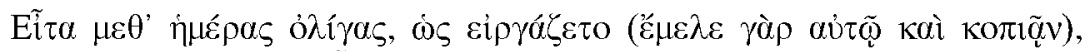

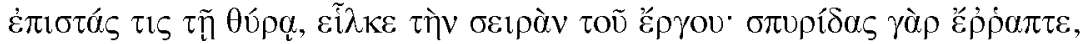

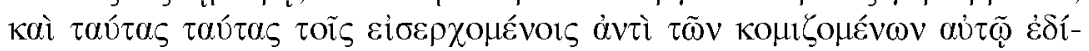

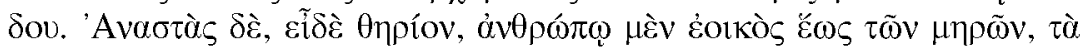

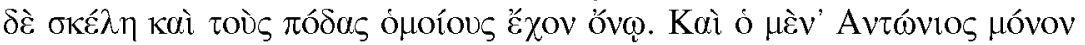

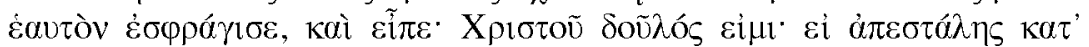

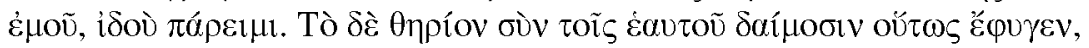

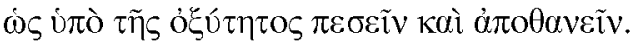

Athanasius depicts his saint doing basketwork in his cell when the Devil shows up unexpectedly. Before his enemy would have time to tempt him, Anthonius makes the sign of the cross and the frightened monster runs away head over heel. (In Palladius we read about a monk who works on his basket, and before the last stitch loses his needle. The Devil, ready to tempt him, gets a lamp, thus infecting him with the sin of presumption. ${ }^{45}$ )

In Jerome's version the first action is temptation, carnal desire and only after this are we told about work as a remedy. Knowing the erotic background of the scene and recalling that the phrase vix ossibus haeret is a quotation from a lovesick Vergilian shepherd, the similarity between the young monk tempted by bodily pleasures and the lovesick Vergilian shepherd can hardly be a coincidence. The indirect quotation from the bucolic song might recall the Second Eclouge, in whose final lines the unhappy shepherd, Corydon speaks to himself as follows: ${ }^{46}$

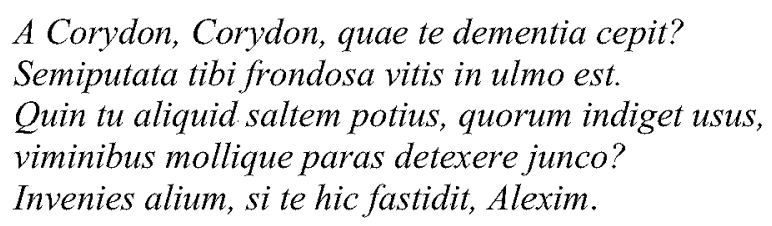

These lines include the phrase iunco (de)texere. In Theocritus' original version the expression is more explicit: the Greek author advises his hero, the lovesick Cyclops to weave baskets as an antidote to pains of the heart: ${ }^{47}$

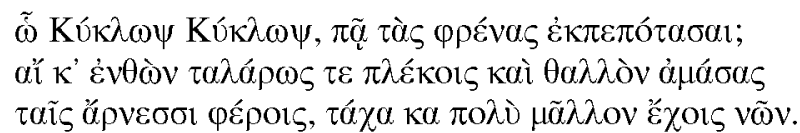

${ }^{44}$ VA 26,920

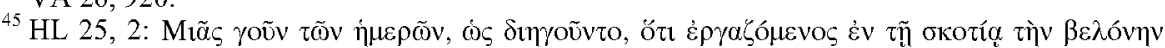

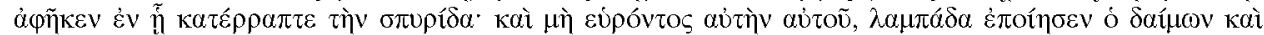

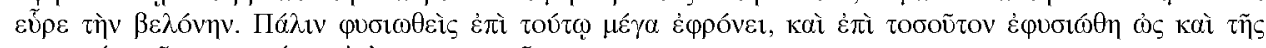

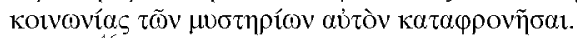

${ }^{46}$ Ecl. 2, 69-73.

${ }^{47}$ Id. $11,72-77$. The word used for baskets is $\tau \alpha \lambda a ́ \rho \omega \varsigma$, like in his original, Book 9 of the Odyssey (246-248). 


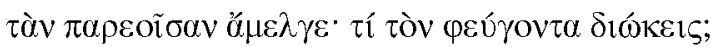

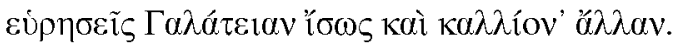

As I mentioned before, Jerome never read Theocritus. He was much better versed in Latin lyric, first of all in Vergil. Besides, he had his own experiences in bodily temptations. Describing the story of Hilarion, tempted by carnal desires, Jerome alludes to Virgil's classical erotic poems (Eclogues 2 and 3): first by using the phrase vix ossibus haeret, the second time by referring to basket-weaving as a remedy for love. Exploring our sources, then, we can forge an interesting link between Vergil's Corydon, the Cyclops' burning love for a mermaid and the young Hilarion tempted by carnal desire.

Jerome must have been aware of how dangerous his literary experiment was. In order to create some sort of equilibrium between classical culture and Christian tradition, he tries to legitimize his hidden allusions to Virgil: instead of naming his poetical source he refers to the apostolic command - qui non operatur non manducet and to the Egyptian monastic tradition of basket-weaving.

As Quintilian says, quotations play an important role in a work of art: Neque enim dubitari potest quin artis magna pars contineatur imitatione ${ }^{48}$ Jerome was aware of this more than any other Latin Father. Unfortunately his endeavour to integrate classical literature and the apostolic tradition remained without followers. Augustine, for instance, in his essay entitled De opere monachorum - written nine years after Jerome's work - whose main topic is the same sentence of Paul - qui non operatur non manducet - does not use any classical quotations.

Pázmány Péter Catholic University

Department of Classical Philology

H-2087 Piliscsaba, Egyetem u. 1.

${ }^{48}$ Inst. or. $10,2,1.2$ 